DOI: $10.1515 / \mathrm{rpp}-2016-0018$

$\mathrm{PhD}$ in Pedagogical Sciences, Senior Researcher, LEILA SULTANOVA Institute of Pedagogical and Adult Education, NAPS of Ukraine Address: 9 M. Berlynskoho St., Kyiv, 04060, Ukraine E-mail: Lala22.07@mail.ru

\title{
ORIGIN AND DEVELOPMENT OF MULTICULTURAL EDUCATION IN THE USA
}

\begin{abstract}
Modern society is undergoing complex social, economic and political transformations of planetary scope due to globalization processes. One of the peculiarities of a modern globalization wave is an intercultural interaction that, in its turn, has resulted in multicultural education. Multicultural education is quite a new branch of pedagogical theory and practice. Its appearance is considered to be connected with a period of complex social and cultural transformations in the USA during 1960s-1970s. However, J. Banks, an American scholar, proves that multicultural education is closely related to African-American movement of the $19^{\text {th }}-20^{\text {th }}$ centuries. Having analyzed the history of origins of multicultural education and stages of its development presented in works by J. Banks and C. Grant we can conclude that the process is associated, predominantly, with migration, and originated as a means of racism prevention. In the course of time the essence of multicultural education was shaped. It became obvious that multicultural education must meet needs of representatives of both different races and social groups. Also, the implementation of multicultural education into practice depends on high-quality professional training of a pedagogue able to work in the context of multicultural society. According to A. Thomas contemporary multicultural education is needed when an individual strives to understand peculiar systems of values, perception, cognition and thinking of people from different cultural backgrounds, integrate new experience into his/her own cultural system and apply it to alien cultural field. Nowadays theory and practice of multicultural education in the USA are still actively developing. Quite high demand are researches of outstanding American scholars and pedagogues in the field of multicultural education, namely, J. Banks, C. Grant, S. Nieto, Ch. Sleeter and many others.

Key words: history of multicultural education, development periodization, multicultural education, intercultural interaction, evolution of multicultural education.
\end{abstract}

\section{INTRODUCTION}

Presently the problem of an intercultural interaction attracts attention of politicians, philosophers, culturists, sociologists as well as pedagogical community since trends in the development of modern society have influenced the direction of state policy towards education development that would be based on the principles of universalization. As a result, multicultural education has become a leading strategy for the development of multicultural society in many countries.

\section{THE AIM OF THE STUDY}

The aim of the paper is 1) to analyze works of American scholars on the history of origins and development of multicultural education in the USA; 2) to characterize stages of multicultural education forming based on the ideas of J. Banks and C. Grant; 3) to define the essence of multicultural education.

\section{THEORETICAL FRAMEWORK AND RESEARCH METHODS}

Theoretical framework of the research comprises the works of such outstanding American scholars as J. Banks, C. Grant, S. Nieto, Ch. Sleeter and many others. 
Methods of study, analysis and generalization of foreign scientific literature on the defined problem were used.

\section{RESULTS}

Having analyzed the processes of forming and development of multicultural education we can single out two authors, namely, J. Banks and C. Grant, who in detail systemized stages of multicultural education forming in the USA (Banks, 1993; Grant, 2008). Their views generally coincide, although there are certain differences.

Thus, in his work named "Multicultural Education: Historical Development, Dimensions, and Practice" J. Banks defines such stages in the development of multicultural education in the USA:

1) the first (ethnological) stage of multicultural education that is characterized by different events organization at the institutional level and practical implementation of concepts and theories of American historians' ethnical researches into pedagogical practice;

2) the second stage (of multiethnic education) that originated due to understanding that the implementation of ethnical researches into educational content and curricula is not sufficient for the school reform aimed at developing more democratic race and ethnic relations. It is necessary that structural and systemic changes in educational practice should be made to enhance educational equality;

3 ) the third stage (improving syllabus) consists in modifying syllabi at schools, colleges and universities that should encompass history and culture of both ethnic and other social groups' representatives that consider themselves to be defective (people with special needs);

4) the fourth stage (of theoretical justification) implies the development of theoretical foundations of multicultural education, research organization and practical implementation of all the components of multicultural education including race, class, sex and other differences.

Within the abovementioned periodization the first stage deserves special attention. Scientific community believes multicultural education first appeared in 1960s and 1970s, whereas J. Banks proves that multicultural education has deep historical roots that go back to African-American movement of the $19^{\text {th }}-20^{\text {th }}$ centuries (Banks, 2010).

Researches of outstanding American scholars serve as evidence since for the first time an attempt was made to integrate data on African-American ethnic group into education content. These are the researches of W. Du Bois, Ch. Wesley, G. Williams, C. Woodson.

The abovementioned scholars strived to oppose to negative views and stereotypes about African-Americans common in educational practice by means of detailed description of their lifestyle, history and contribution to national development. In such a way they raised the status of African-Americans. It was indicated that positive African-Americans' self-perception of their image is extremely important for their communal identity and liberation as well as stereotypes and negative attitude towards African-Americans can be effectively eliminated due to objective historical researches that, in their turn, have caused the transformation of prevailing academic knowledge.

In his report "The Evolution of Multicultural Education in the United States: a Journey for Human Rights and Social Justice" C. Grant associates stages of multicultural education development with social movements within a society.

The first period covers $1930 \mathrm{~s}$ and 1940s and is related to the intercultural movement caused by immigration waves in the USA, in particular, from Western Europe. US ideology on immigrants was intended for assimilation that is full Americanization based on the values of "freedom", "equality" and "justice". At that time the intercultural movement originated being aimed at recognizing immigrants' cultures. The ways to promote 
social adaptation included publication of printed matter available in the languages native to immigrants, organization of different events contributing to their Americanization. In general, the education system of that period was aimed at forming monocultural worldview of oncoming generations. However, not all immigrants wanted to assimilate that caused certain problems and required exceptional attempts from educators.

The second period (1940s and 1950s) occurred within the intercultural educational movement. The society was facing racial tensions caused by migration of rural population, mostly African-Americans, into towns. This resulted in an abundance of public organizations that protected the rights of African-Americans. In educational environment topical became the researches of reasons for intergroup conflicts. "The Nature of Prejudice" by G. Allport is the most famous among them (Allport, 1954).

The revealed social and psychological patterns of intergroup conflicts enabled the development of curricula promoting intergroup tolerance and peaceful resolution of conflicts as well as programmes designed to prevent racial tensions.

The next period (the middle of 1950s - the middle of 1960s) involves the Civil Rights Movement aimed at abolishing laws and traditions by race. Significant changes were made in the legislature of the USA. As a result, the idea of juridical equality for all American citizens of any race was deeply rooted into social consciousness. Though the movement failed to overcome discrimination completely, multicultural education became a powerful social tool to form an equal society.

C. Grant considers the last period (1960s - 1970s) to be "the movement of ethnic researches) as textbooks and didactic illustrations were studied to reveal information on the culture of different ethnic groups.

It should be mentioned that during this period profound social changes took place in American society. African-Americans and other ethnic groups resisted assimilation and tried to preserve their cultural identity and heritage. They demanded that their culture be included into curricula at schools, colleges and universities to ensure balanced involvement of children into both the culture of the majority and their own cultural traditions. Thus, cultural heritage of the USA required reconsideration to meet educational needs of the society that became multicultural.

Appealing against predominant conceptions teaching was based on close associates of multicultural education justified the need to modify curricula that would take into account different views and thereby transform eurocentric perspective.

During this period such US education organizations as the National Council for Social Studies, the National Council of Teachers of English, the American Association of Colleges for Teacher Education led the campaign that stipulated for inclusion of an ethnic component into syllabi and curricula.

In particular, National Council for the Social Studies published the 1976 Curriculum Guidelines for Multiethnic Education where key principles on development of multiethnic education curricula were presented (National Council for the Social Studies, 1976). In 1992 the guidelines were reviewed and republished as a textbook for multicultural education, though.

A turning moment for multicultural education became a ratification of the 1977 Standards for Accreditation of Teacher Education by The National Council for Accreditation of Teacher Education (NCATE) that provide compulsory use of multicultural education courses and programmes by all NCATE members (approximately $80 \%$ ) (National Council for Accreditation of Teacher Education, 2008). In addition, NCATE and US Department of Education insisted that courses and trainings on multicultural education should be included 
into professional training of future teachers since 1980s. In the states of California, Florida and Massachusetts future teachers were trained in the context of multicultural education and teaching English as a second language (The Glossary of Education Reform, 2013).

Meanwhile for the first time the International Dictionary of Education published in London in 1977 presented the definition of "multicultural education" being a situation of interaction among those studying with unfamiliar cultural elements and realities, in other words, as a reflection of ideals of cultural pluralism in education (Thomas, Marshall, 1977).

It should be mentioned that multicultural education was initiated to solve education problems of national minorities. In the very context multicultural education is presented in most works. Nowadays, it is used in a wider meaning as intercultural interaction occurs not only among national minorities but also different social and cultural communities within a nation.

These definitions are focused rather on a group than a personality. Our study is mainly dedicated to a personality of an instructor in a higher education pedagogical institution. We agree with an interpretation of multicultural education by a German professor of intercultural psychology A. Thomas who believes that multicultural education is needed when a personality strives to understand peculiar systems of values, perception, cognition and thinking of people from different cultural backgrounds, integrate new experience into his/her own cultural system and apply it to alien cultural field. Multicultural education as well understanding of values systems in other cultures provides for reflection of one's own cultural system. Multicultural education is successful provided synthesis among culturally divergent systems of values is achieved that enables to cooperate in both native and alien cultures (Thomas, 1988).

Such an explanation of multicultural education reveals various aspects of the phenomenon and is characterized by a high degree of interdisciplinarity.

Thus, while forming multicultural education the system of education in the USA underwent significant changes. It became obvious that multicultural education must meet needs of representatives of both different races and social groups. Also, the implementation of multicultural education into practice depends on high-quality professional training of a pedagogue able to work in the context of multicultural society. At the end of 1980 s all these factors were taken into account during carrying out education reforms.

Nowadays theory and practice of multicultural education in the USA are still being actively developed. Quite high demand are researches of outstanding American scholars and pedagogues in the field of multicultural education, namely, J. Banks, C. Grant, S. Nieto, Ch. Sleeter and many others.

J. Banks singles out five dimensions of multicultural education: content integration, knowledge construction process, prejudice reduction, equity pedagogy, empowering school culture and social structure (Banks, 1993).

Content integration is the use of information on different cultures and social groups in the content of subjects.

Knowledge construction process provides for teaching aimed at the development of critical thinking towards the same object or phenomenon. Thus, an instructor helps students to form an idea of a phenomenon or object under the influence of racial, ethnic, social and class positions of a society or an individual.

Prejudice reduction helps to understand the dependence of ethnic identity on the context of learning, views and beliefs of prevailing social groups.

Equity pedagogy consists in an individual approach to students of different racial, cultural, social and economic and language-specific groups to enhance academic progress. 
Empowering school culture and social structure expects the achievements of equal opportunities for students.

Despite the fact that each dimension differs conceptually, they are interconnected in practice. In 2009 C. Grant and Ch. Sleeter co-wrote the textbook under the title "Turning on Learning: Five Approaches for Multicultural Teaching Plans for Race, Class, Gender and Disability" where they suggested five ways for practical application of data on diversity during the educational process (according to race, class, sex, disability) based on multicultural principles (Grant, Sleeter, 2008). S. Nieto is the author of numerous books and articles. In her last publication "Finding the Joy in Teaching Students of Diverse Backgrounds" published in 2013 she presented interviews with pedagogues who reflected upon the efficiency of teaching representatives of different cultures in reality (Nieto, 2013).

All abovementioned scholars are members of National Association for Multicultural Education founded in 1990. It became the main national and international organization engaged in issues of justice, integration, diversity and equality in educational establishments. Apart from them other scholars in the field of multicultural education should be acknowledged. They are H. Baptiste, Ph. Chinn, D. Gollnick, W. Howe, P. Lisi, A. Marbley.

\section{CONCLUSIONS}

So, multicultural education is a relatively new field of pedagogical theory and practice. The forming of multicultural education has transformed the understanding of its essence and widened its content. Multicultural education in the USA is still developing. In Ukraine it has only started its forming. However, nowadays, it is extremely topical for the national system of education and is rather significant in theory and practice of future instructors' professional training.

\section{REFERENCES}

1. Allport, G. (1954). The Nature of Prejudice. Cambridge MA : Addison-Wesley, 537 p.

2. Banks, J. (1993). Multicultural Education: Historical Development, Dimensions, and Practice. Review of Research in Education, Volume19, pp. 3-49.

3. Banks, J., Ambrosio, J. (2010). Multicultural Education - History, the Dimensions of Multicultural Education, Evidence of the Effectiveness of Multicultural Education. Retrieved 1.04.2016 from : http://education.stateuniversity.com/pages/2252/Multicultural-Education.html.

4. Grant, C., Sleeter, C. (2008). Turning on Learning: Five Approaches for Multicultural Teaching Plans for Race, Class, Gender and Disability. New York : John Wiley \& Sons, 352 p.

5. Grant, C. (2008). The Evolution of Multicultural Education in the United States: A Journey for Human Rights and Social Justice. Retrieved 2.04.2016 from : http://libguides.rutgers.edu/c.php?g=336784\&p=2267275.

6. National Council for Accreditation of Teacher Education. (2008). Professional Standards for the Accreditation of Teacher Preparation Institutions. Washington DC : NCATE, $92 \mathrm{p}$.

7. National Council for the Social Studies. (1976). Curriculum Guidelines for Multiethnic Education: Position Statement. Arlington (Va) : National Council for the Social Studies, 48 p.

8. Nieto, S. (2013). Finding the Joy in Teaching Students of Diverse Backgrounds. Portsmouth, NH : Heinemann, $200 \mathrm{p}$.

9. The Glossary of Education Reform. (2013). Multicultural Education. Retrieved 1.04.2016 from : http://edglossary.org/multicultural-education/.

10. Thomas, A. (1988). Interkulturelles Lernen im Schüleraustausch [Intercultural Learning in School Exchange]. Saarbrücken u. Fort Lauderdale : Breitenbach, 265 p. (in German).

11. Thomas, J., Marshall, A. (1977). International Dictionary of Education. London : Kogan Page, 381 p. 